\title{
Protective Effects of Flavonoid Pomiferin on Heart Ischemia-Reperfusion
}

\author{
J. NEČAS, L. BARTOŠÍKOVÁ, T. FLORIAN ${ }^{1}$, J. KLUSÁKOVÁ ${ }^{2}$, V. SUCHÝ ${ }^{1}$, E. JANOŠTÍKOVÁ ${ }^{1}$, \\ T. BARTOŠÍK ${ }^{2}$, EM. B. EL NAGGAR ${ }^{1}$ \\ Department of Physiology, Faculty of Medicine and Dentistry, Palacký University Olomouc \\ ${ }^{1}$ Pharmaceutical Faculty, University of Veterinary and Pharmaceutical Sciences Brno \\ ${ }^{2}$ St. Anne Teaching Hospital Brno \\ Received January 23, 2006 \\ Accepted June 5, 2007
}

\begin{abstract}
Nečas J., L. Bartošíková, T. Florian, J. Klusáková, V. Suchý, E. Janoštíková, T. Bartošík, EM. B. El Naggar: Protective Effects of Flavonoid Pomiferin on Heart IschemiaReperfusion. Acta Vet. Brno 2007, 76: 363-370.

The objective of the present 15-day study was to evaluate the cardioprotective potential of flavonoid pomiferin isolated from the infructences of Maclura pomifera, Moraceae, against ischemia-reperfusion induced injury in rat hearts as a model of antioxidant-based composite therapy. Studies were performed with isolated, modified Langendorff-perfused rat hearts and ischemia of heart was initiated by stopping the coronary flow for $30 \mathrm{~min}$, followed by $60 \mathrm{~min}$ of reperfusion $\left(14 \mathrm{ml} \cdot \mathrm{min}^{-1}\right)$. Wistar rats were divided into three groups. The treated group received pomiferin $(5 \mathrm{mg} / \mathrm{kg} /$ day in $0.5 \%$ Avicel); the placebo group received only $0.5 \%$ Avicel; the intact group was left without any applications. Biochemical indicators of oxidative damage, lipid peroxidation product malondialdehyde, antioxidant enzymes (superoxide dismutase, glutathione peroxidase, total antioxidant activity in serum and myocardium has been evaluated. We also examined the effect of pomiferin on cardiac function (left ventricular end-diastolic pressure, left ventricular pressure, peak positive $+\mathrm{dP} / \mathrm{dt}$ (rate of pressure development) after ischemia and reperfusion. Our results demonstrate that pomiferin attenuates the myocardial dysfunction provoked by ischemiareperfusion. This was confirmed by the increase in both the antioxidant enzyme values and the total antioxidant activity. The cardio-protection provided by pomiferin treatment results from the suppression of oxidative stress and correlates with the improved ventricular function.
\end{abstract}

Maclura pomifera, pomiferin, cardioprotection, superoxide dismutase, glutathione peroxidase, total antioxidative capacity, cardiac function

Many superior plant compounds have a protective effect on human health and they are used in the treatment of a wide range of diseases in popular medicine. Flavonoids belong to these classes of compounds. They are commonly present in human diet, especially in fruit and vegetables, and their daily intake is ca $1-2 \mathrm{~g}$. Many of their effects on plant and animal cells are significant (Lee et al. 1998; Havsteen 2002; Rao et al. 2005). In oncology the flavonoids are used as corroborative compounds, reducing the side effects of cytostatics, and on the other hand, they enhance therapeutical effects; this field is very well documented (Kandaswami et al.1991; Nishino et al. 2004; Scambia et al.1992; Śtípek 2000).

Flavonoids are often used in the treatment of inflammation because of their ability to inhibit the key enzyme in prostaglandines (PG) synthesis - cyclooxygenase (COX) (O’Leary et al. 2004; Seaver and Smith 2004; Selvam et al. 2004). They were tested in post-transplantation conditions, too (Bayer et al. 2004; Zhong et al. 2004).

Flavonoids, a heterogeneous group of phenol compounds, are effective antioxidants in the case of oxidative injury (Manach and Donovan 2004; Valachovicova et al. 2004). They prevent lipid peroxidation, scavenge free oxygen radicals, and inactivate pro-oxidative metal ions (iron, copper). The scavenging activity is one of the best known properties and it represents a significant therapeutic use (Maxwell and Lip 1997; Urquiaga and Leighton

Address for correspondence:

Doc. MUDr. Jiří Nečas, PhD.

Department of Physiology, Faculty of Medicine and Dentistry

Palacký University Olomouc

Hněvotínská 3, 77515 Olomouc, Czech Republic
Phone: +420 585632351

Fax: +420 585632368

E-mail: jiri.necas@tunw.upol.cz

http://www.vfu.cz/acta-vet/actavet.htm 
2004). The antioxidant activity of the flavonoids depends on the number and position of hydroxyl groups in their molecules and on their glycosylation. The optimal properties were found in the flavonoids with the ortho-hydroxy structure on ring B; 2,3 double bond, and 4-oxo functional group in the ring $\mathrm{C}$, and 3 and $5-\mathrm{OH}$ groups on the rings $\mathrm{A}$ and $\mathrm{C}$ (Aherne and O'Brien 2002).

Among various reactive oxygen species (ROS) generated during the pathological processes that cause or accompany $I / R$ injury (Racek et al. 1995), superoxide plays the key role. In spite of being a free radical, it is not highly reactive; however, the superoxide radical anion appears to play a central role, since other reactive intermediates are formed in reaction sequences starting with it. According to the fact that the physiological functions of the heart are conditioned by a remarkable consumption of oxygen, the elimination of superoxide radical during $\mathrm{I} / \mathrm{R}$ is one of the possible therapeutic interventions. In the present study we have examined whether it is possible to affect the origination of superoxide and its metabolic derivates experimentally during the heart I/R secondary to the 15 days oral administration $(5 \mathrm{mg} / \mathrm{kg} /$ day) of flavonoid pomiferin. Pomiferin (Fig. 1) belongs to the group of prenylated isoflavones. The compounds were isolated from the fruits of Maclura pomifera (Raf.) Schneid. (Moraceae).

\section{Materials and Methods}

\section{Extract preparation}

Grinded fruits of Maclura pomifera, Moraceace were obtained from South Moravia and subjected to consecutive Soxhlet extraction using methanol, which yielded yellow crystals of osajin-pomiferin mixture after cooling. The crystals were filtered, washed and dissolved in hot methanol.

Pomiferin was separated from osajin by the addition of lead acetate which reacts with the two hydroxyl groups at the position 3 and 4 on ring $B$ of pomiferin to form a light yellow insoluble coagulate, while osajin remains in the solution, having only one hydroxyl group on ring B; osajin was then further re-crystallized from the methanolic solution after concentration under vacuum.

\section{Procedure of separation}

Ten grams of osajin-pomiferin crystals were dissolved in $200 \mathrm{ml}$ of hot methanol and then mixed with $15 \mathrm{~g}$ of lead acetate trihydrate (dissolved in $20 \mathrm{ml}$ methanol). The light yellow coagulate created over night was filtered and then rinsed with hot acetone.

Osajin was obtained by re-crystallization from the thickened methanol and acetone solutions.

For the purpose of identification and purity ascertainment of pomiferin during all the extraction process, reversed phase high performance liquid chromatography was performed using the Muscar method.

Reversed phase high performance liquid chromatography (Muscar method)

The HPLC (HP 1100) system consists of quaternary pump, autosampler, thermostatic column compartment, and diode array detector. The analytical column was Supelcosil ABZ + Plus and LC-8, $15 \mathrm{~cm} \times 4.6 \mathrm{~mm}, 3 \mu \mathrm{m}$. Mobile phase consisted of two eluents, (A) acetonitrile and (B) $40 \mathrm{mM}$ formic acid. Separation of compounds was carried out with the gradient elution profile: $1^{\text {st }}$ min, $70: 30$; during $15 \mathrm{~min}, 100: 0$. Chromatography was performed at $40{ }^{\circ} \mathrm{C}$ with a flow-rate of $1.0 \mathrm{ml} / \mathrm{min}$, and detection was at $280 \mathrm{~nm}$ and $350 \mathrm{~nm}$.

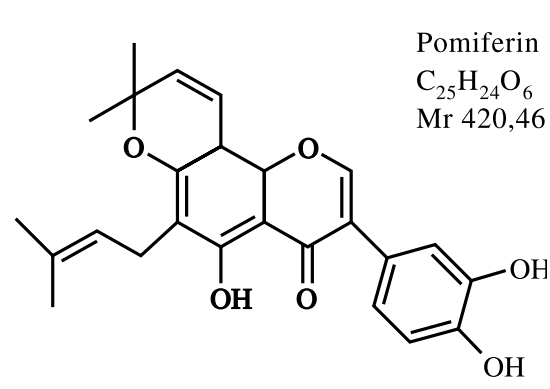

Fig. 1. Chemical structure of pomiferin

\section{Animals and therapy}

The study and its experimental protocol were approved and monitored by the Ethics Committee of the University of Veterinary and Pharmaceutical Sciences in Brno. The state of health of all animals was inspected regularly several times a day both during the acclimation of the animals and in the course of the whole experiment performed by the work group, whose members are holders of the Eligibility Certificate issued by the Central Commission for Animal Protection pursuant to Section 17 of the Czech National Council Act No. 246/1992 Coll. on animal protection against maltreatment.

This study was performed on 30 male Wistar SPF (AnLab, Germany) laboratory rats of identical age (6 months) and comparable weight $(354 \pm 27 \mathrm{~g})$. The animals were housed at a standard controlled temperature, fed a standard diet for small laboratory animals, and given water $a d$ 


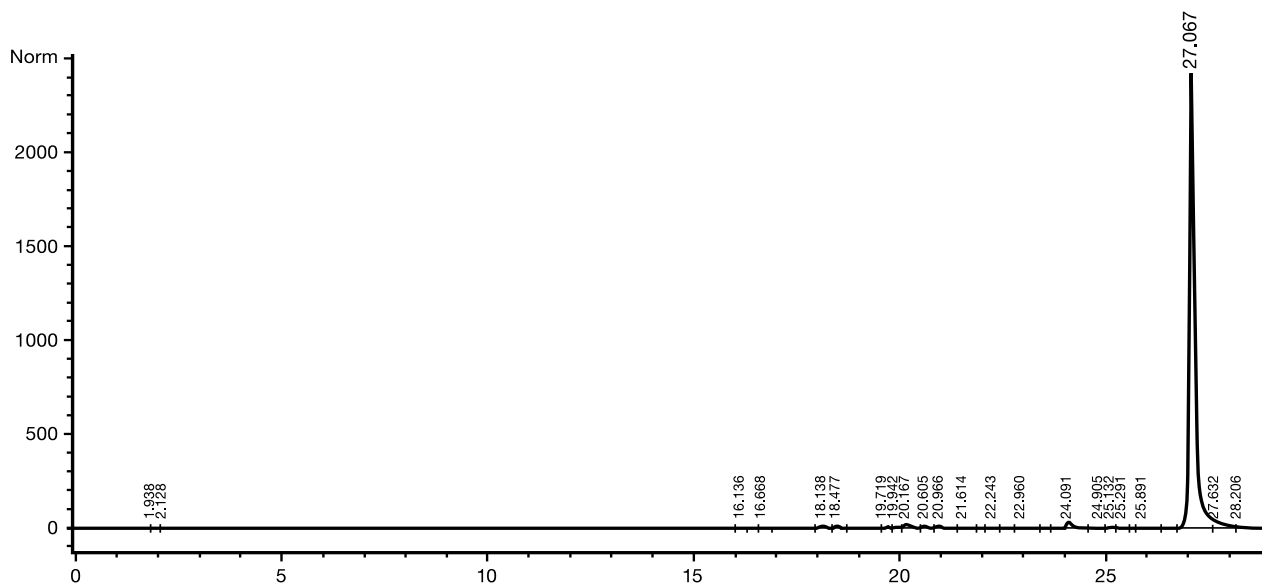

Fig. 2. High-performance liquid chromatogram of pomiferin from infructencence of Maclura pomifera, Moraceae (Supelcosil ABZ + Plus method Muscar).

libitum. After a recovery period, the animals were divided randomly into 3 groups (ten rats in each group):

The first group (treated group) received pomiferin daily at a dose of $5 \mathrm{mg} \cdot \mathrm{kg}^{-1}$ solved in $2 \mathrm{ml}$ of $0.5 \%$ Avicel solution orally by intragastric tube (Vetchy and Rabiskova 2002). The second group (placebo group) received only $0.5 \%$ Avicel in the same quantity $(2 \mathrm{ml})$ and by the same application method as the treated group. The last group of the animals (intact group) was left without treatment or Avicel.

Experimental design

At the end of the treatment period (15 days) the rats were anaesthetized with an intraperitoneal injection of anaesthetical mixture ( $2 \%$ Rometar $0.5 \mathrm{ml}+1 \%$ Narkamon $10 \mathrm{ml}$, dose $0.5 \mathrm{ml}$ solution $/ 100 \mathrm{~g}$ body weight). The blood was collected from the left subclavian vein and biochemical indicators were examined. No blood sample was haemolytic. The evaluated blood biochemical indicators were: malondialdehyde (MDA) serum values - TBARs method, total antioxidant activity (TAA) in heparinized plasma, glutathione peroxidase (GSHPx) in heparinized blood, superoxide dismutase (SOD) in erythrocytes, using RANDOX testing kits (Dublin, Ireland).

After the intraperitoneal administration of heparine injection at the dose of $500 \mathrm{IU}$, the hearts were excised and perfused. In all experiments, the modified Langendorff method and the universal apparatus Hugo Sachs Electronic UP 100 (Germany HSE) were used. Working schedule: stabilization-ischaemia-reperfusion were proceeded at intervals $20-30-60 \mathrm{~min}$.

Biomechanical indicators from the isolated heart, i.e. left ventricle pressure (LVP), end-diastolic pressure (LVEDP), contractility ( $\mathrm{dP} / \mathrm{dt}_{\mathrm{max}}$ ) were measured using a ball filled with liquid ( $\left.8-12 \mathrm{mmHg}\right)$, inserted through the left atrium in the left ventricle connected to the analog convertor (Isotec HSE, DIF modul HSE) (Kozlovski et al. 2004). After completing the reperfusion, the heart was cooled in liquid nitrogen and stored at a temperature of $-80^{\circ} \mathrm{C}$ for further analyses. Lipid peroxidation assessment: in supernatant of the heart homogenate in saline, the TBAR $_{S}$ value was assessed by the spectroscopic method (Buege and Aust 1978). Antioxidant enzyme activities: Cellular GSH peroxidase (GSHPx) activity (Flohé and Gunzler 1984; Kakkar et al. 1984); cellular SOD activity (Spitz and Oberley 1989; Wendel 1981).

Preparation of the rat heart homogenate and measured biochemical indicators

Tissue homogenate was prepared in a ratio of $1 \mathrm{~g}$ of wet tissue to 10 times (w/v) $0.05 \mathrm{M}$-ice cold phosphate buffer ( $\mathrm{pH}$ 7.4) and homogenized by using a DI 25 Basic, Germany homogenizer. Myocardial thiobarbituric acid reactive substances $\left(\mathrm{TBAR}_{\mathrm{S}}\right.$ ) (Buege and Aust (1978) (a marker of lipid peroxidation), and endogenous antioxidants superoxide dismutase (Flohé and Gunzler 1984; Kakkar et al. 1984) and glutathione peroxidase (GSHPx) were measured in all the groups (Spitz and Oberley 1989; Wendel 1981).

Lipid peroxidation assay

The lipid peroxidation was assessed by studying thiobarbituric acid reactive substances (TBAR ${ }_{s}$ ) by the method previously described by Buege and Aust (1978). Aliquots of the supernatant were added to a pyrex tube that contained trichloracetic acid $(10 \%)$ and thiobarbituric acid $(0.67 \%)$ and incubated at $100{ }^{\circ} \mathrm{C}$ for 15 minutes. The mixture was allowed to cool on ice for $5 \mathrm{~min}$. This was followed by the addition of $1.5 \mathrm{ml}$ of n-butyl-alcohol; the mixture was vigorously agitated for $40 \mathrm{~s}$ and centrifuged at $1000 \mathrm{~g}$ for $15 \mathrm{~min}$, in order to extract the resulting chromogen. The TBAR value were assessed by the spectroscopic method (spectrophotometer Unicam UV 300 , $\mathrm{GB})$ at the absorbance of $532 \mathrm{~nm}$ and calculated using the coefficient $1.56 \times 105 \mathrm{M}^{-1} \mathrm{~cm}^{-1}$, expressed as nmol $\mathrm{MDA} / \mathrm{g}$ of tissue. Commercially available malondialdehyde was used as a standard. 
Antioxidant enzyme activities

Assay of cellular GSH peroxidase activity: Cellular GSH peroxidase (GSHPx) activity was measured by the method of Flohé and Gunzler (1984) and of Kakkar et al. (1984). Briefly, to an assay cuvette containing $0.5 \mathrm{ml}$ of $50 \mathrm{mM}$ potassium phosphate ( $\mathrm{pH} 7.0$ ), $1 \mathrm{mM}$ EDTA, and $2 \mathrm{mM}$ sodium azide, $100 \mu \mathrm{l}$ of sample, $100 \mu \mathrm{l}$ of $10 \mathrm{mM} \mathrm{GSH}, 100 \mu \mathrm{l}$ of glutathione reductase $(2.4 \mathrm{U} / \mathrm{ml})$, and $100 \mu \mathrm{l}$ of $1.5 \mathrm{mM}$ NADPH were added. The cuvette was incubated at $37^{\circ} \mathrm{C}$ for $3 \mathrm{~min}$. After the addition of $100 \mu \mathrm{l}$ of $2 \mathrm{mM} \mathrm{H}_{2} \mathrm{O}_{2}$, the rate of NADPH consumption was monitored at $340 \mathrm{~nm}, 37^{\circ} \mathrm{C}$ for $5 \mathrm{~min}$. This was designated as the total rate of NADPH consumption. The non-enzyme dependent consumption of NADPH was also measured as above except that the $100 \mu \mathrm{l}$ of sample was replaced by $100 \mu \mathrm{l}$ of sample buffer. The rate of enzyme-dependent NADPH consumption was obtained by subtracting the non-enzyme-dependent NADPH consumption rate from the total NADPH consumption rate. GSHPx activity was calculated using the extinction coefficient of $6.22 \mathrm{mM}^{-1} \mathrm{~cm}^{-1}$ and expressed as nanomoles of NADPH consumed per min per milligram of cellular protein.

Assay of cellular SOD activity

Total cellular SOD activity was determined by the method of Spitz and Oberley (1989) and of Wendel (1981) with slight modifications. Briefly, the reaction mix (to be prepared freshly) contained in $50 \mathrm{mM}$ potassium phosphate buffer, $\mathrm{pH} 7.8,1.33 \mathrm{mM}$ diethylenetriaminepentaacetic acid, $1.0 \mathrm{U} / \mathrm{ml}$ catalase, $70 \mu \mathrm{M}$ nitroblue tetrazolium, $0.2 \mathrm{mM}$ xanthine, $0.05 \mathrm{mM}$ bathocuproinedisulfonic acid, and $0.13 \mathrm{mg} / \mathrm{ml} \mathrm{BSA}$. As much as $0.8 \mathrm{ml}$ of the reaction mix was added to each cuvette, followed by addition of $100 \mu \mathrm{l}$ of sample. The cuvettes were prewarmed at $37^{\circ} \mathrm{C}$ for $3 \mathrm{~min}$. The reaction was then started by adding $100 \mu \mathrm{l}$ of XO $(0.1 \mathrm{U} / \mathrm{ml})$. The formation of formazan blue was monitored at $560 \mathrm{~nm}, 37{ }^{\circ} \mathrm{C}$ for $5 \mathrm{~min}$. The sample total SOD activity was calculated using a concurrently run SOD (Sigma Chemical) standard curve and expressed as units per milligram of cellular protein.

\section{Statistical analysis}

The obtained values of the studied biochemical indicators were processed by the Microsoft ${ }^{\circledR}$ Excel $^{\circledR}$ table processor and statistically evaluated using UNISTAT programme, ANOVA test and unpaired Student's $t$-test. All values are expressed as mean \pm SEM. Statistical differences with a value $p \leq 0.05$ were considered significant.

\section{Results}

\section{Biochemical results \\ Blood}

After the oral administration of pomiferin for the period of 15 days, the MDA values were found to be significantly $(p \leq 0.01)$ decreased in treated group as compared to the placebo and intact animal groups.

The serum TAA values were significantly $(p \leq 0.01)$ reduced in the placebo and intact animal groups in comparison to that of the pomiferin-treated group.

The superoxide dismutase (SOD) values were significantly $(p \leq 0.01)$ highly increased in the treated animals as compared to the placebo and the intact animal groups.

The GSHPx values were significantly $(p \leq 0.01)$ increased in the treated animals as compared to that of the placebo and the intact animal groups. The results are summarized in Table 1.

Heart, myocardial MDA, activity of myocardial GSHPx and activity of myocardial SOD

There was a significant $(p \leq 0.01)$ decrease in myocardial MDA in pomiferin treated group ( $5 \mathrm{mg} / \mathrm{kg} /$ day) as compared to that of placebo and intact groups. No significant change was noted in myocardial $\mathrm{TBAR}_{\mathrm{S}}$ between placebo and intact groups.

There was no significant change in myocardial GSHPx activity between treated, placebo and intact groups, respectively.

There was a significant $(p \leq 0.05)$ reduction in myocardial SOD activity in placebo and intact group when compared to that of treated group. No significant change was noted in myocardial SOD between placebo and intact group. See Table 2.

Biomechanical results of the heart

Fig. 3 shows the effect of pomiferin on LVP during ischemia and reperfusion. In hearts from placebo and intact animals LVP recovered until $64 \pm 7$ and $65 \pm 6 \%$ of preischemic values at the end of the reperfusion. While hearts from the pomiferin pretreated animals, 
Table 1. Effect of pomiferin application on MDA, TAA, SOD and GSHPx

\begin{tabular}{|c|c|c|c|c|c|}
\hline $\begin{array}{l}\text { Animal } \\
\text { groups } \\
(n=10)\end{array}$ & Dose & $\begin{array}{c}\text { MDA } \\
(\mathrm{mmol} / \mathrm{L})\end{array}$ & $\begin{array}{c}\text { TAA } \\
(\mathrm{mmol} / \mathrm{L})\end{array}$ & $\begin{array}{l}\text { SOD } \\
(\mathrm{U} / \mathrm{ml})\end{array}$ & $\begin{array}{l}\text { GSHPx } \\
(\mu \mathrm{kat} / 1)\end{array}$ \\
\hline $\begin{array}{l}\text { Treated } \\
\text { with } \\
\text { pomiferin }\end{array}$ & $\begin{array}{c}5 \mathrm{mg} / \mathrm{kg} / \mathrm{day} \\
\text { in } 0.5 \% \\
\text { Avicel } \\
\text { solution }\end{array}$ & $\begin{array}{c}0.08 \pm 0.08 \\
* *++\end{array}$ & $\begin{array}{c}0.49 \pm 0.03 \\
* *++\end{array}$ & $\begin{array}{c}232.23 \pm \\
17.62 \\
* *++\end{array}$ & $\begin{array}{c}1569.48 \pm \\
133.93 \\
* *++\end{array}$ \\
\hline $\begin{array}{c}\text { Placebo } \\
\text { group }\end{array}$ & $\begin{array}{l}0.5 \% \text { Avicel } \\
\text { solution }\end{array}$ & $1.77 \pm 0.12$ & $0.41 \pm 0.04$ & $70.39 \pm 2.79$ & $\begin{array}{c}1229.10 \pm \\
120.45\end{array}$ \\
\hline Intact group & ------- & $1.89 \pm 0.16$ & $0.43 \pm 0.03$ & $67.37 \pm 3.97$ & $\begin{array}{c}1121.37 \pm \\
152.21\end{array}$ \\
\hline
\end{tabular}

$* * \mathrm{p} \leq 0.01$ treated vs. placebo group

$++\mathrm{p} \leq 0.01$ treated vs. intact group

Table 2. Values of myocardial MDA, activity of myocardial GSHPx and activity of myocardial SOD

\begin{tabular}{|l|c|c|c|c|}
\hline $\begin{array}{l}\text { Animal } \\
\text { groups } \\
(\mathbf{n}=10)\end{array}$ & Dose & $\begin{array}{c}\text { MDA } \\
\text { (nmol/mg } \\
\text { protein) }\end{array}$ & $\begin{array}{c}\text { GSHPx activity } \\
\text { (nmol/min/mg } \\
\text { protein) }\end{array}$ & $\begin{array}{c}\text { SOD } \\
\text { (units/mg } \\
\text { protein) }\end{array}$ \\
\hline $\begin{array}{l}\text { Treated } \\
\text { with } \\
\text { pomiferin }\end{array}$ & $\begin{array}{c}5 \mathrm{mg} / \mathrm{kg} / \mathrm{day} \\
\text { in } 0.5 \% \\
\text { Avicel } \\
\text { solution }\end{array}$ & $\begin{array}{c}2.67 \pm 0.21 \\
* *++\end{array}$ & $62.0 \pm 2.5$ & $\begin{array}{c}6.7 \pm 0.5 \\
*+\end{array}$ \\
\hline $\begin{array}{l}\text { Placebo } \\
\text { group }\end{array}$ & $\begin{array}{c}0.5 \% \text { Avicel } \\
\text { solution }\end{array}$ & $4.55 \pm 0.15$ & $65.5 \pm 5.0$ & $5.6 \pm 0.6$ \\
\hline $\begin{array}{l}\text { Intact } \\
\text { group }\end{array}$ & ------ & $4.71 \pm 0.19$ & $68.0 \pm 4.0$ & $5.8 \pm 0.7$ \\
\hline
\end{tabular}

** $\mathrm{p} \leq 0.01$ treated vs. placebo group

* $\mathrm{p} \leq 0.05$ treated vs. placebo group $++\mathrm{p} \leq 0.01$ treated vs. intact group

$+\mathrm{p} \leq 0.05$ treated vs. intact group

showed significantly improved postischemic recovery, reaching LVP values of $98 \pm 8 \%$ at the end of the reperfusion.

Fig. 4 shows the changes elicited in the pomiferin treated animals. In hearts from placebo and intact animals LVEDP rise from $10.0 \pm 0.5$ to $44 \pm 3$ and $43 \pm 4 \mathrm{mmHg}$, respectively, after $60 \mathrm{~min}$ of reperfusion. This increase was diminished in the hearts of the pomiferin pre-treated animals. LVEDP was $30 \pm 2$ at the end of reperfusion.

Fig. 5 shows the effect of pomiferin on $\mathrm{dP} / \mathrm{dt}_{\max }$ during ischemia and reperfusion. The pretreatment with pomiferin improved $+\mathrm{dP} / \mathrm{dt}_{\max }$ recovery during reperfusion to $93 \pm 4 \%$ at 60 min of reperfusion. These values were significantly higher than those obtained from the placebo and intact hearts $(73 \pm 5$ and $72 \pm 4 \%)$.

\section{Discussion}

Oxygen is critical to myocardial cell aerobic metabolism and maintenance of highenergy stores for normal myocardial function. Acute ischemia results in a spectrum of derangements, which range from transient reversible arrest of the myocardium, to severe irreversible abnormalities. Ischemia-reperfusion injury is a complex process; the excessive production of oxygen-free radicals is the main mechanism involved in I/R injury (Kaneko et al. 1994; Štípek 2000). In the heart, oxygen radicals may be generated by several 
Fig. 3: LVP

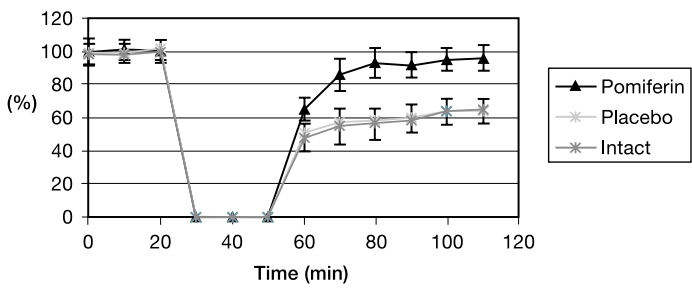

Fig. 3. Left ventricular pressure, LVP (\%)

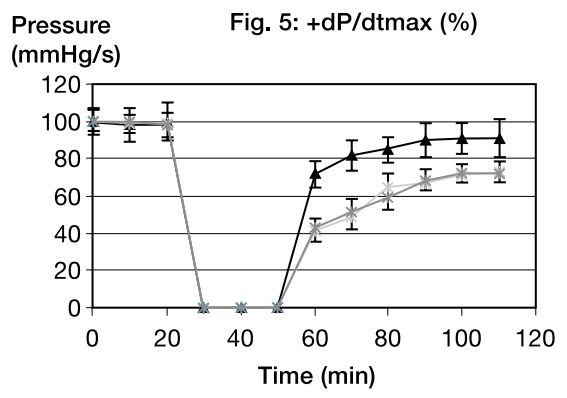

Fig. 5. $+\mathrm{dP} / \mathrm{dt}_{\max }(\%)$; legend see Fig. 3

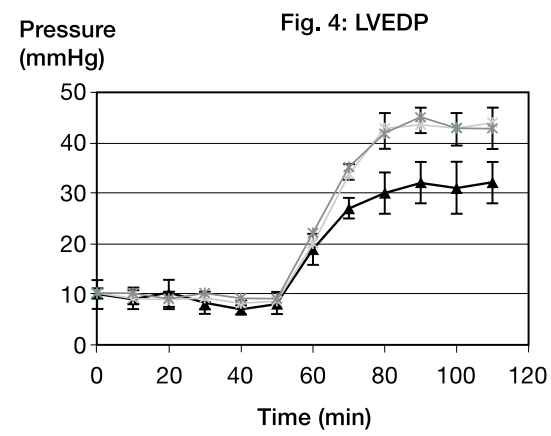

Fig. 4. Left ventricular end-diastolic pressure LVEDP (mmHg); legend see Fig. 3

mechanisms, suchasmitochondrial respiration, activated neutrophils and, in some species, by xanthine oxidase activity. The release of free radicals (superoxide and hydroxyl radical) in the early phase of reperfusion, in combination with the I/R-induced decrease in antioxidant activity, renders the myocardium extremely vulnerable. The fact that free oxygen radicals play a significant role during the heart $I / R$ is well known, being accompanied by superoxide dismutase, glutathione peroxidase depletion and reduction of the total antioxidant activity that act as natural oxygen radical scavengers in the organism.

The aim of the performed study was the assessment of the cardioprotective effect of the flavonoid pomiferin separated from Maclura pomifera, Moraceae (Lee et al. 1998). The effects of pomiferin were studied on ischemia-reperfusion injury in rats as a model of antioxidant-based composite therapy.

The antioxidant protection under the conditions of inducing oxidative injury is a complex system in which the separate antioxidant elements co-operate with one another. The function of one antioxidant often conditions the effects of another element in the system. Dismutation of superoxide by SOD is the first step of the enzymatic cascade leading to the complete detoxification of free radicals. However, the product of its activity, $\mathrm{H}_{2} \mathrm{O}_{2}$, is still a toxic agent. The second step corresponds to the transformation of $\mathrm{H}_{2} \mathrm{O}_{2}$ to $\mathrm{H}_{2}^{2} \mathrm{O}$ via hydroperoxidases such as catalase or glutathione peroxidase.

It is evident that the increase of the SOD activity can be noxious for the organism, since it can produce $\mathrm{H}_{2} \mathrm{O}_{2}$ (a precursor of the hydroxyl radical) at a faster rate than that at which hydroperoxidases can remove it.

GSHPx is only able to act in the presence of sufficient amount of reduced glutathione (GSH). GSH is oxidized to GSSG, and then GSSG (oxidized glutathione) can be reduced to (GSH) by the NADPH-dependent flavoenzyme glutathione reductase in order to maintain GSH-Px activity. Thus, the ratio of GSSG to GSH is believed to be an excellent antioxidant marker during intracellular oxidative stress.

Natural antioxidants can react with different radicals through different mechanisms; they can affect one another (synergy, inhibition). Therefore we have measured the total antioxidant activity which quantifies the capacity of radical elimination in a biological material sample. After 15 days of pomiferin oral administration TAA serum values were statistically significantly $(p \leq 0.01)$ reduced in the placebo and intact animal 
groups in comparison with the pomiferin-treated group $(0.41 \pm 0.04$ and $0.43 \pm 0.03$ vs. $0.49 \pm 0.03)$.

After the 15-day oral administration of pomiferin at the dose of $5 \mathrm{mg} / \mathrm{kg}$, the serum MDA values were significantly $(p \leq 0.01)$ decreased in treated group as compared to that of the placebo and intact animals $(0.80 \pm 0.08$ vs. $1.77 \pm 0.12$ and $1.87 \pm 0.16)$.

Our results confirmed that there was a significant decrease in the myocardial MDA values in the pomiferin treated group as compared to that of the placebo and intact animal groups, which confirmed the capacity to prevent lipid peroxidation induced by I/R injury.

The findings from serum and myocardium supported the functional changes in the treated hearts in comparison with placebo and intact groups.

In the hearts of placebo and intact animals LVP recovered up to $64 \pm 7$ and $65 \pm 8 \%$ of preischemic values at the end of the reperfusion. On the other hand, in the pomiferin pretreated animals the hearts significantly improved the post-ischemic recovery, reaching LVP values of $98 \pm 8 \%$ at the end of the reperfusion.

In the hearts of placebo and intact animals LVEDP rose from $10.0 \pm 0.5$ to $44 \pm 3$ and $43 \pm 4 \mathrm{mmHg}$, respectively, after $60 \mathrm{~min}$ of reperfusion. This increase was diminished in the hearts obtained from the pomiferin pre-treated animals to $30 \pm 2$ at the end of reperfusion.

The pre-treatment with pomiferin improved $+\mathrm{dP} / \mathrm{dt}_{\max }$ recovery during reperfusion to 93 $\pm 4 \%$ at $60 \mathrm{~min}$ of reperfusion. These values were significantly greater then those obtained from the placebo and intact hearts $(73 \pm 5$ and $72 \pm 4 \%)$.

It can be deduced from the results of our experiment that the administration of pomiferin to laboratory rats has a cardioprotective potential against ischemia-reperfusion induced injury in rat hearts as a model of antioxidant-based composite 15-day therapy. This was confirmed by the increase in both the antioxidant enzyme values and the total antioxidant activity that occur even at the dose of $5 \mathrm{mg} / \mathrm{kg} / \mathrm{day}$. This effect is also demonstrated in the functional indicators of hearts, LVP, LVEDP and $+\mathrm{dP} / \mathrm{dt}$

In conclusion, the results from the present study suggests that the flavonoid pomiferin has a potent cardioprotective effect on perfused rat hearts subjected to global ischemia and reperfusion. Its effects may be mediated through the inhibition of lipid peroxidation.

Flavonoid pomiferin can antagonize myocardial injury induced by I/R through inhibiting oxidative stress. In this work, pre-treatment with pomiferin at the dose of $5 \mathrm{mg} / \mathrm{kg} / \mathrm{day}$ significantly decreased the myocardial lipid peroxide production of MDA and indicated that pomiferin could have an inhibiting effect on oxidative stress induced by I/R. Although the flavonoid pomiferin seems to be protective with a probable effect against the oxidative injury induced by the heart I/R, its effect and optimal method of administration have to be explained.

\section{Protektivní vliv flavonoidu pomiferinu na ischemii-reperfuzi srdce}

Studie se zabývá kardioprotektivním potenciálem flavonoidu pomiferinu, izolovaného z plodů Maclura pomifera, Moraceae, na modelu izolovaného perfundovaného myokardu v podmínkách ischemicko-reperfuzního poškození. Studie byla provedena na izolovaných srdcích laboratorního potkana, které byly perfundovány modifikovanou metodou dle Langendorffa. Po stabilizační, 10 minutové fázi (koronární perfuze $14 \mathrm{ml} \cdot \mathrm{min}^{-1}$ ) byla navozena ischémie srdce zástavou perfuze na dobu 30 minut, poté následovala reperfuze na dobu 60 minut (průtok $14 \mathrm{ml} \cdot \mathrm{min}^{-1}$ ).

Zvířata byla rozdělena do 3 skupin $(\mathrm{n}=10)$. První skupina - léčená (pomiferin $5 \mathrm{mg} / \mathrm{kg}$ v $0.5 \%$ Avicelu); placebo skupina ( $0.5 \%$ Avicel); intaktní skupina - bez aplikace. Látky byly podávány $\mathrm{v}$ jedné denní dávce, perorálně, gastrickou sondou, po dobu 15 dnů.

Sledovány byly biochemické indikátory oxidativního poškození: malondialdehyd, supe- 
roxid dismutáza, glutathion peroxidáza, celková antioxidační kapacita $\mathrm{v}$ séru, respektive v myokardu. Dále byly sledovány parametry srdeční funkce: end-diastolický tlak v levé komoře, tlak v levé komoře a kontraktilita.

Výsledky dokazují, že pomiferin zmírní dysfunkce myokardu provokované navozenou ischémií-reperfuzí. Tuto skutečnost potvrzuje vzestup aktivity antioxidačních enzymů a celkové antioxidační kapacity v séru. Kardioprotekce podávaným flavonoidem vychází ze suprese oxidativního stressu a koreluje se zachováním ventrikulární funkce izolovaného srdce.

\section{References}

AHERNE SA, O'BRIEN NM 2002: Dietary flavonoids: Chemistry, food content, and metabolism. Nutrition 18: 75-81

BAYER J, GOMER A, DEMIR Y, AMANO H, KISH DD, FAIRCHILD R, HEEGER PS 2004: Effects of green tea polyphenols on murine transplant-reactive T cell immunity. Clin Immunol 110: 100-108

BUEGE JA, AUST SD 1978: Microsomal lipid peroxidation. Method Enzymol 52: 302-309

FLOHÉ L, GUNZLER WA 1984: Assays of glutathione peroxidase. Method Enzymol 105: 114-121

HAVSTEEN BH 2002: The biochemistry and medical significance of the flavonoids. Pharmacol Ther 96: 67-202

KAKKAR P, DAS B, VISWANATHAN PN 1984: A modified spectrophotometric assay of superoxide - dismutase. Indian J Biochem Biol 21: 130-132

KANDASWAMIC, PERKINS E, SOLONIUK DS, DRZEWIECKI G, MIDDLETONE JR 1991: Antitproliferative effects of citrus flavonoids on a human squamous - cell carcinoma in vitro. Cancer Lett 56: 147-152

KANEKO M, MATSUMOTO Y, HAYASHI H, KOBAYASHI A, YAMAZAKI N 1994: Oxygen - free radicals and calcium homeostasis in the heart. Mol Cell Biochem 139: 91-100

KOZLOVSKI VI, VDOVICHENKO VP, CHLOPICKI S, MALCIK SS, PRALIYEV ZD, ZCILKIBAYEV OT 2004: Antiarrhytmic profile and endothelial action of novel decanhydroquinoline derivatives. Pol J Pharmacol 56: $767-774$

LEE SJ, WOOD AR, MAIER CGA, DIXON RA, MABRY TJ 1998: Prenylated flavonoids from Maclura pomifera. Phytochemistry 49: 2573-2577

MANACH C, DONOVAN JL 2004: Pharmacokinetics and metabolism of dietary flavonoids in humans. Free Rad Res 38: 771-785

MAXWELL SRJ, LIP GYH 1997: Reperfusion injury: A review of the pathophysiology, clinical manifestations and therapeutic options. Int J Cardiol 58: 95-117

NISHINO H, TOKUDA H, SATOMI Y, MASUDA M, OSAKA Y, YOGOSAWA S, WADA S, MOU XY, TAKAYASU J, MURAKOSHI M, JINNNO K, YANO M 2004: Cancer prevention by antioxidants. Biofactors 22: 57-61

O'LEARY KA, DE PASCUAL-TEREASA S, NEEDS PW, BAO YP, O'BRIEN NM, WILLIAMSON G 2004: Effect of flavonoids and Vitamin E on cyclooxygenase-2 (COX-2) transcription Mutat Res 551: 245-254

RACEK J, VESELÁ E, HOLEČEK V, TŘEŠKA V 1995: The significance of free radicals in patients with renal failure and kidney transplantation. Klin Biochem Metab 3(Suppl.): 4-6

RAO YK, FANG SH, TZENG YM 2005: Anti-inflammatory activities of flavonoids isolated from Caesalpinia pulcherrima. J Ethnopharmacol 100: 249-253

SCAMBIA G, RANELLETTI FO, PANICI PB, PIANTELLI M, BONANNO G, DE VINCENZO R, FERRANDINA G, MAGGIANO N, CAPELLI A, MANCUSO S 1992: Inhibitory effect of quercetin on primary ovarian and endometrial cancers and synergistic activity with cis-diamminedichloroplatinum. Gynecol Oncol 45: 13-19

SEAVER B, SMITH JR 2004: Inhibition of COX isoforms by nutraceuticals. J Herb Pharmacother 4: 11-18

SELVAM C, JACHAK SM, BHUTANI KK 2004: Cyclooxygenase inhibitory flavonoids from the stem bark of Semecarpus anacardium Linn. Phytother Res 18: 582-584

SPITZ DR, OBERLEY LW 1989: An assay for superoxide - dismutase activity in mammalian tissue homogenates. Anal Biochem 179: 8-18

ŠTíPEK S 2000: Antioxidanty a volné radikály ve zdraví a nemoci. Grada Publishing, Praha, pp. 117-137

URQUIAGA I, LEIGHTON F 2000: Plant polyphenol antioxidants and oxidative stress. Biol Res 33: 55-64

VALACHOVICOVA T, SLIVOVA V, SLIVA D 2004: Cellular and physiological effects of soy flavonoids. Mini Rev Med Chem 4: 881-887

VETCHY D, RABISKOVA M 2002. Some variables influencing rotoagglomeration in the multiprocessor MP-1. Int J Pharm 242: 353-356

WENDEL A 1981: Glutathione peroxidase. Method Enzymol 77: 325-333

ZHONG Z, CONNOR HD, FROH M, LIND H, BUNZENDAHL H, MASON RP, THURMAN RG, LEMASTERS JJ 2004: Polyphenols from Camellia sinenesis prevent primary graft failure after transplantation of ethanolinduced fatty livers from rats. Free Radic Biol Med 36: 1248-1258 